\title{
Application of Resistivity Method Wenner- Schlumberger Array to Evaluate Brantas River Embankment as Avoid Landslide
}

\author{
Firdha Kusuma Ayu Anggraeni ${ }^{1}$, Eko Minarto ${ }^{1}$, and Arie Realita ${ }^{1}$
}

\begin{abstract}
The maintenance of embankment is important to avoid some damages like landslide. Brantas river passes 6 cities, include Mojokerto. Landslide of Brantas embankment was occured at Lengkong and Mlirip, Mojokerto. The location of landslide is near from crowded highway. Therefore evaluation using resistivity method is needed to identification vulnerability of landslide. There are 4 line of data acquisition. First, suspected there are seepage at point 25-35 $m$ and fracture at point 65-75 $\mathrm{m}$ from dam. Then, second line, there is a suspect of fracture at point 65-90 $\mathrm{m}$ and seepage at point 110-125 m. Third line, at point 20-35 $\mathrm{m}$ and 110-140 $\mathrm{m}$ are suspected as fracture and at point 55-75 $m$ is suspected as seepage. The last line is indicated that the embankment was good.
\end{abstract}

Keywords- embankment, geophysics, fracture, seepage, wenner-schlumberger.

\section{INTRODUCTION}

Embankment foundation along the river is useful to protect human life [1]. Maintenance of embankment is important to keep the function of river properly. Body of embankment can suffer some damages that caused by landslide at embankment slope, leakage of embankment foundation, and internal erosion [2]. All of the damages caused by some factors like porosity of the material, seepage, fracture, and overburden at slope of the embankment [3].

Brantas is the second biggest river in Java. One of region that passed by Brantas is Mojokerto [4]. The failed function of embankment cause the landslide was occured at Lengkong and Mlirip, Mojokerto. The location of landslide is near from crowded highway. Therefore evaluation is needed to identification vulnerability to landslide. The evaluation using geophysics survey. One of the method is resistivity. Fundamental of electrical resistivity method is injecting current to the ground and measuring potential difference using potential electrode around current injected [5]. The evaluation using WennerSchlumberger array because the research expected obtain the result in lateral and sounding to find sructure of the subsurface.

The research at Brantas, Mojokerto itself has never done before. Researchs about the landslide of embankment have been done by [6] that discussed about scouring as the potency of lanslide at Bengawan Solo embankment used GPR method, [7] that discussed about GPR and resistivity method to evaluated the safety level of embankment, Aitsebaomo et al [2] that written the utilization of electromagnetic method for erosion surveying at embankment, and [8] discussed about investigation and monitoring internal erosion and seepage anomaly at embankment using resistivity method. Hopefully from this research can obtained efective result so that it can investigate the potency of landslide in Brantas embankment at Lengkong and Mlirip Mojokerto. Therefore the research can give information to local society and service to be more cautious to landslide of the embankment.

\section{METHOD}

The research to evaluate Brantas embankment at Lengkong and Mlirip Mojokerto has been done using resistivity method Wenner-Schlumberger array. The research use four line. Fig. 1 describe about the line of the research. Blue line is first line with length $100 \mathrm{~m}$, red line is second line with length $200 \mathrm{~m}$ green line is third line with length $200 \mathrm{~m}$, and the yellow line is last line with length $130 \mathrm{~m}$. The result that obtained from the measurement is resistance value which then calculated to obtain resistivity value as data analysis. Resistivity value is processing by Res2dinv software. The characteristics of subsurface can be known and analysed by compare the resistivity value from inversion result to table reference that describe resistivity value of some material of the earth and data logging of research location.

\section{RESULTS AND DISCUSSION}

Based on processing data using Res2dinv has been obtained three section. First section is called measured apparent resistivity pseudosection, second section is calles calculated apparent resistivity pseudosection, and the third section is called inverse model resistivity section. First line is described by Fig. 2 below. From inverse model, first line has range of resistivity value 2,22-199 ohm-m. This value (comparing with table reference and data logging) indicates that materials of subsurface consist of water, sand, sand-gravel, and sandclay. The anomaly at first line occured at point 35-45 m (A-B) that suspected as seepage of the water because it has lower resistivity value. The other anomaly occured at point 60-75 m (C-D) that suspected as fracture which consist of air. The inversion result using resistivity then compared by inversion using another method i.e VLF which is done by Realita [9]. Inversion of VLF shown by Fig. 3. Inversion result shown that at point $40-50 \mathrm{~m}(\mathrm{E}-\mathrm{F})$, there is lower resistivity value that indicates as seepage and at point 70$80 \mathrm{~m}(\mathrm{G}-\mathrm{H})$ there is fracture consist of air. Both resitivity and VLF shown that first line has range resistivity value 
of subsurface 0-200 $\mathrm{m}$ and the point where the seepage and fracture was occured shown by similar resistivity value.

Then, inversion of second line shown by Fig.4. The range of resistivity value is about $1,24-244 \mathrm{ohm}-\mathrm{m}$. From that value, the material of subsurface is similar like first line. There are two anomalies, at point $65-90 \mathrm{~m}$ (A-B) that suspected as fracture consists of air and at point 110-125 $\mathrm{m}(\mathrm{C}-\mathrm{D})$ that suspected as seepage.

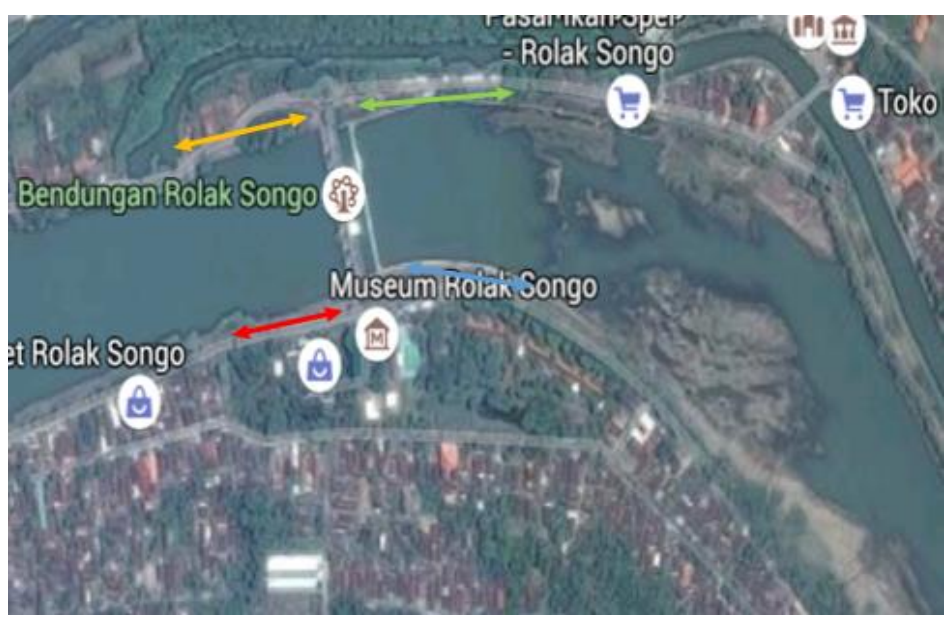

Figure. 1. Location of the research from google earth.
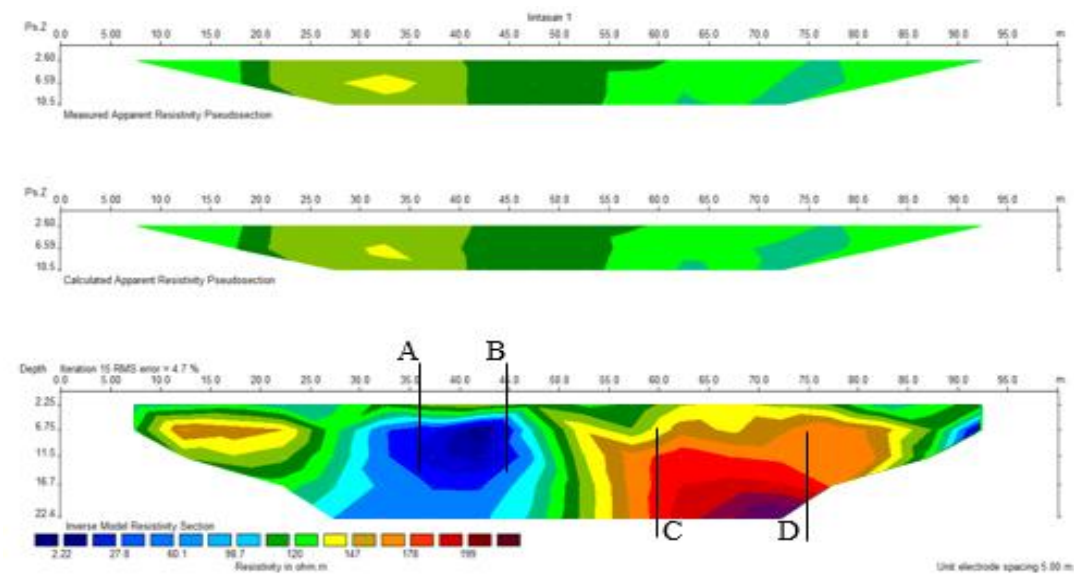

Figure 2. Section of first line.

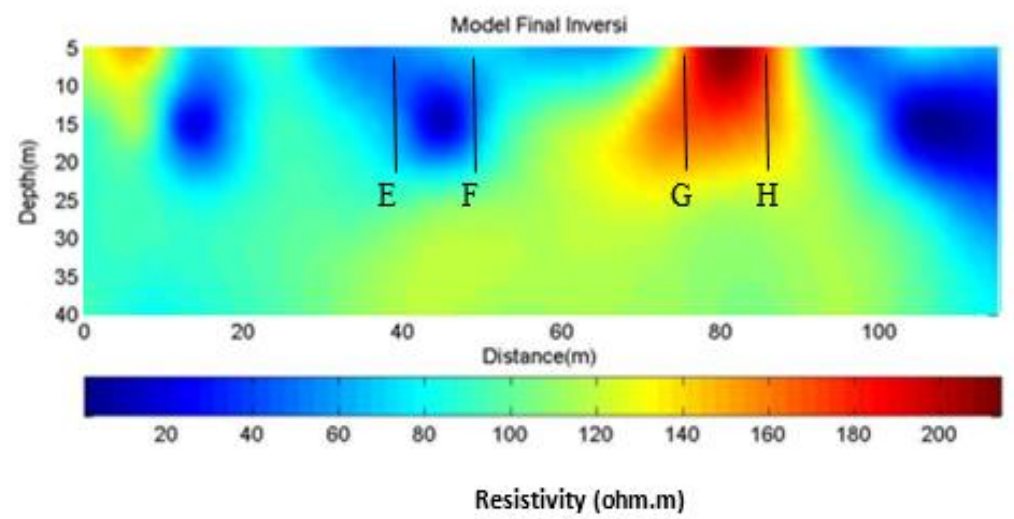

Figure 3. Inversion model of first line using VLF method.

The inversion result using resistivity compared by VLF method [6] that shown by Fig. 5. From VLF method explain that at point $45-80 \mathrm{~m}(\mathrm{E}-\mathrm{F})$ suspected as fracture and at point $95-120$ $\mathrm{m}(\mathrm{G}-\mathrm{H})$ suspected as seepage. Third line has range of resistivity value $3-181 \mathrm{ohm}-\mathrm{m}$ and the subsurface consist of similar material like first and second line. The inversion model shown by Fig.6. The result obtain higher resistivity value that suspected as fracture consists of air at point $20-35 \mathrm{~m}$ (A-B) and 110-140 (E-F) $\mathrm{m}$ and then at point 55-75 $\mathrm{m}(\mathrm{C}-\mathrm{D})$ has lower value. The inversion resul compared by VLF method. Inversion model shown by Fig. 7. From VLF inversion, the fracture is occured around $20 \mathrm{~m}(\mathrm{G}-\mathrm{H})$ and $140 \mathrm{~m}(\mathrm{~K}-\mathrm{L})$, and seepage is occured at point $60-80 \mathrm{~m}(\mathrm{I}-\mathrm{J})$. 

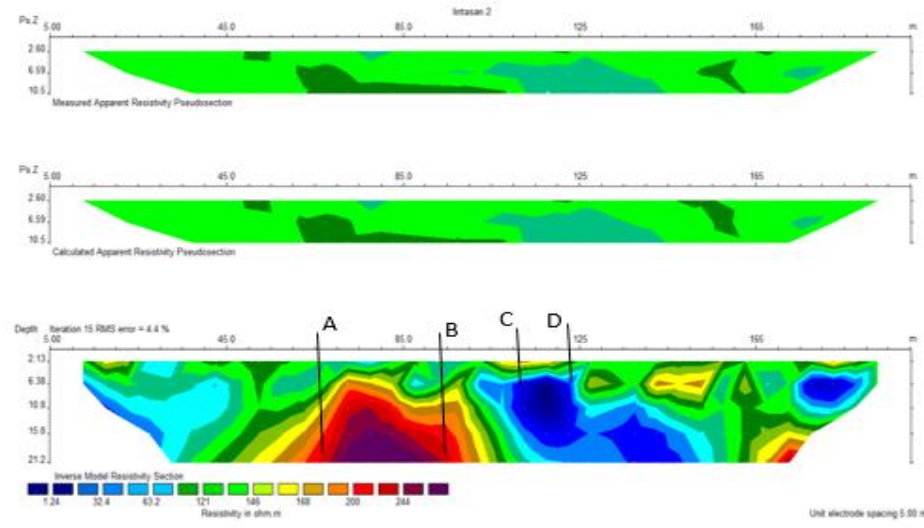

Figure. 4. Section of second line.

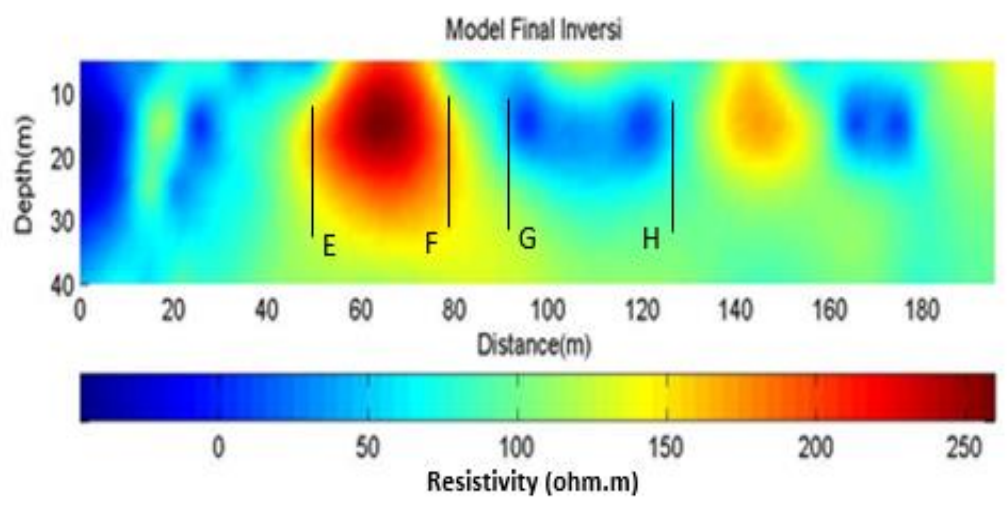

Figure. 5. Inversion result of second line with VLF method.
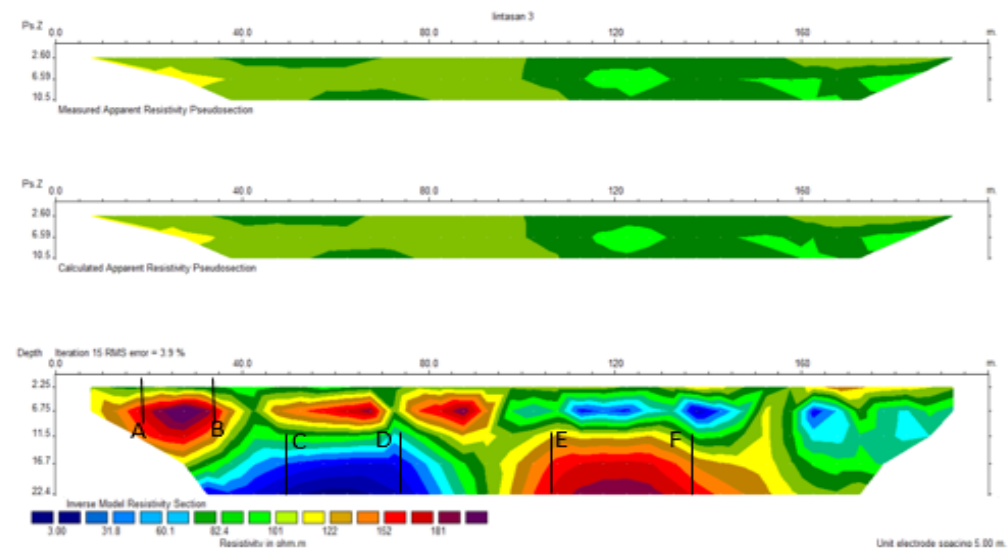

Figure. 6. Inversion result of third line.

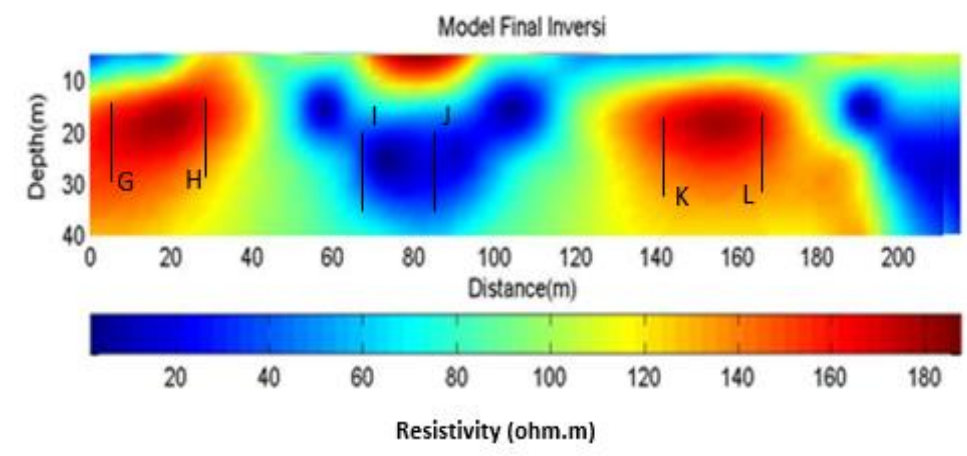

Figure. 7. VLF inversion of third line. 


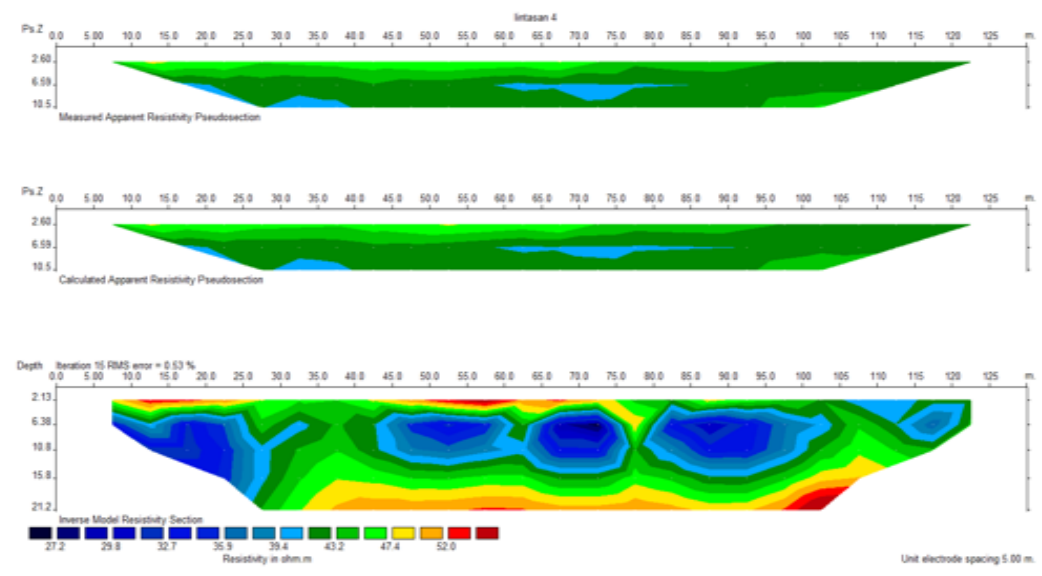

Figure. 8. Section of fourth line.

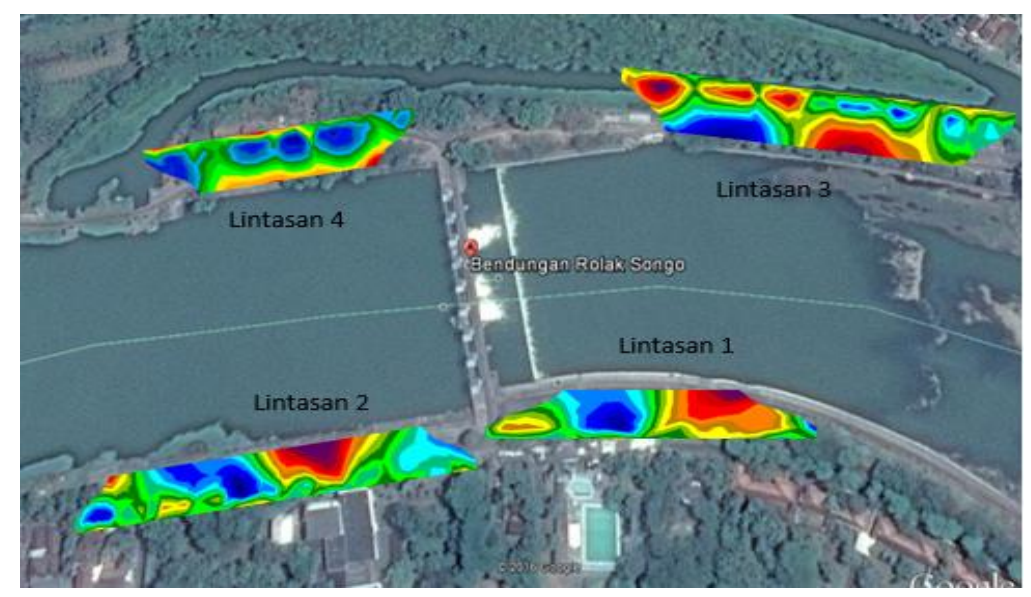

Figure. 9. Vertical section for all lin

Fourth line has range of resistivity value 27,2-52 ohm$\mathrm{m}$ shown by Fig. 8 . From this resistivity value the material of subsurface consist of sand, sand gravel, and sandclay. The result of the embankment at line 4 is obtained that no anomaly in there. The vertical section is shown by Fig. 9 . From the measurement is obtained evaluation result i.e first line, second line, and third line have potency of landslide, fourth line has no potency or minimum of potency of landslide.

Fourth line has range of resistivity value 27,2-52 ohm$\mathrm{m}$ shown by Fig. 8 . From this resistivity value the material of subsurface consist of sand, sand gravel, and sandclay. The result of the embankment at line 4 is obtained that no anomaly in there. The vertical section is shown by Fig. 9 . From the measurement is obtained evaluation result i.e first line, second line, and third line have potency of landslide, fourth line has no potency or minimum of potency of landslide.

\section{CONCLUSION}

Based on the research in the line 1,2, and 3 there are suspects of seepages and fracture consists of air. The embankment of these three line can be considered less worthy or less secure so that have high potency of landslide. Meanwhile, fourth line is suspected no fracture or seepage. Therefore these embankment of fourth line still feasible or in a good condition.

\section{REFERENCES}

[1] Sosrodarsono, S.,1985. Perbaikan dan Pengaturan Sungai, Pt. Pradnya Paramita, Jakarta.

[2] Aitsebaomo, F.O., O. Adeyami, and H.A Quadri. 2013."Electromagnetic Survey of Erosion in Awba, Ibadan Nigeria Embankment Dam". International Journal of Engineering and Science, Vol. 3, Issue 3, pp 01-05.

[3] Hardiyatmo, Hary Christadi, 2006. Penangangan Tanah Longsor dan Erosi. Gadjah Mada University Press, Yogyakarta.

[4] Balai Besar Wilayah Sungai Brantas .2011. www.pu.go.id/uploads/services/2011-11-30-11-37-29.pdf.

[5] Mainali, Ganesh. 2006. Monitoring of Tailing Dams with Geophysical Methods. Thesis. Lulea University of Technology.

[6] Warnana, Dwa Desa. 2008."Identifikasi Scouring sebagai Potensi Kelongsoran Tanggul Sungai Bengawan Solo Berdasarkan Survei GPR (Studi Kasus Desa Widang, Kabupaten Tuban)". Jurnal Fisika dan Aplikasinya, Vol.4, No,2.

[7] Mori, Guido. 2009. The Use of Ground Penetrating Radar and Alternative Geophysical Technique for Assessing Embankments and Dykes Safety. Doctoral Thesis. Department of Earth and Geoenvironmental Science, University of Bologna.

[8] Sjodahl, Pontus.2006. Resistivity Investigation and Monitoring for Detection of Internal Erosion and Anomalous Seepage in Embankment Dams. Doctoral Thesis. Engineering Geology, Lund University : Sweden.

[9] Realita, Arie. 2016. Aplikasi Metode Very Low Frequency Electromagnetic Untuk Mitigasi Bencana Longsor Di Area Tanggul Sungai Brantas Mojokerto. Tesis Magister, Institut Teknologi Sepuluh Nopember, Surabaya. 